\title{
PENGARUH METODE "BRISK WALKING EXERCIXE" TERHADAP PENURUNAN TEKANAN DARAH PADA PASIEN HIPERTENSI DI UPT PELAYANAN SOSIAL LANJUT USIA KISARAN RANTAU PRAPAT TAHUN 2020
}

\author{
Niasty Lasmy Zaen ${ }^{1}$, Fitri Sinaga ${ }^{2}$ \\ STIKes Rumah Sakit Haji Medan, Indonesia
}

\section{Article Info}

\section{Keywords:}

Hypertension

Smoking

Brisk Walking Exercixe

\begin{abstract}
Blood pressure is the pressure that is urged by circulating blood in the walls of blood vessels, and is one of the vital signs of the principal technique in reducing blood pressure Brisk walking exercise. blood pressure in hypertensive patients at UPT Elderly Social Services Range in Prapat Overseas Range in 2020. This study used a pre-experimental design study One Group pre-test and posttest design. The population in this study were all elderly who had hypertension in the UPT Elderly Social Services Range in 2020, as many as 50 elderly people using the Purposive Sampling technique in which the research sample was 40, the statistical analysis of the data used in this study was univariant and bivarian namely using the Wilcoxon Test. Based on the results of the study there was a significant effect between blood pressure before and after the Brisk Walking Exertice, with a p value $(0,000)<\alpha(0.05)$. For further researchers can improve and pay attention to the number of sex characteristics and pay more attention to the procedures given. Future researchers can also compare brisk walking exercise techniques with other aerobic sports.
\end{abstract}

This is an open access article under the CC BY-SAlicense.

This is an open access article under the CC BY-SAlicense.
Corresponding Author:
Niasty Lasmy Zaen,
Program Studi D-III Kebidanan,
STIKes Rumah Sakit Haji Medan,
Jl. Rumah Sakit H., Medan Estate, Kec. Percut Sei Tuan, Kabupaten Deli Serdang, Medan-Sumatera Utara.
Email: niastyzaen @ yahoo.com

\section{INTRODUCTION}

Tekanan darah adalah tekanan yang didesakkan dengan mensirkulasi darah pada dinding pembuluh darah, dan merupakan salah satu tanda-tanda vital yang prinsipil. Tekanan dari pensirkulasian darah menurun ketika ia bergerak menjauh dari jantung melalui pembuluh arteri dan kapiler serta menuju jantung melalui pembuluh vena. Ketika tidak memenuhi syarat, tekanan darah biasanya mengacu pada tekanan pembuluh arteri yang ada di tangan, yaitu dalam pembuluh darah utama pada lengan kiri atau kanan bagian atas yang membawa darah dari jantung (A.j. Ramadhan, 2018).

Menurut Undang-Undang Nomor 13 Tahun 1998 dalam Azizah (2011) tentang kesejahteraan lanjut usia pada bab I pasal layat 2, yang dimaksud lanjut usia adalah seseorang yang mencapai usia 60 tahun keatas. Lansia merupakan proses alami yang dialami oleh semua orang, dimasa ini seseorang akan 
mengalami kemunduran fisik, mental dan sosial secara bertahap. Kemunduran fungsi organ juga terjadi pada lansia yang menyebabkan kelompok ini rawan terhadap penyakit-penyakit kronis seperti Diabetes Melitus, stroke, gagal ginjal dan hipertensi. Salah satu masalah kesehatan yang sering terjadi pada masa usia lanjut adalah hipertensi atau tekanan darah tinggi (Kemenkes RI, 2013).

Salah satu masalah kesehatan yang sering terjadi pada masa usia lanjut adalah hipertensi atau tekanan darah tinggi. Hipertensi merupakan terjadinya peningkatan secara abnormal dan terus menerus tekanan darah yang disebabkan satu atau beberapa faktor yang tidak berjalan sebagaimana mestinya dalam mempertahankan tekanan darah secara normal (Levine \& Fodor, 2013). Hipertensi pada usia lanjut sebagian besar merupakan hipertensi sistolik terisolasi (HST) (Kuswardhani, 2016). Hipertensi sistolik terisolasi adalah hipertensi yang terjadi ketika tekanan sistolik lebih dari $140 \mathrm{mmHg}$ namun tekanan diastolik dalam batas normal (Wahid, 2017).

Sekitar $60 \%$ lansia akan mengalami hipertensi etelah berusia 75 tahun. Hal ini merupakan pengaruh degenerasi yang terjadi pada orang yang bertambah usianya. Data dari The National Health and Nutrition Examination Survey (NHANES) menunjukkan bahwa dari tahun 2000-2015, insiden hipertensi pada orang dewasa adalah sekitar 29-31\%, yang berarti terdapat 58-65 juta penderita hipertensi di Amerika (Yogiantoro, 2016). Berdasarkan data Depkes (2015), prevalensi hipertensi di Indonesia sebesar 31.7\%. Cakupan diagnosis hipertensi oleh tenaga kesehatan hanyamencapai $24.0 \%$,ataudengan katalainsebanyak76.0\% kejadian hipertensi dalam masyarakat belum terdiagnosis. Dari hasil studi tentang kondisi sosial ekonomi dan kesehatan lanjut usia yang dilaksanakan Komnas Lansia di 10 propinsi tahun 2012, diketahui bahwa hipertensi menduduki peringkat kedua penyakit terbanyak yang diderita lansia setelah penyaki tsendi (Depkes, 2016).

Berdasarkan data dari Riskesdas (2013), hipertensi di Indonesia merupakan masalah kesehatan dengan prevalensi yang tinggi yaitu sebesar 25,8\%. Prevalensi tertinggi di Bangka Belitung (30,9\%), diikuti Kalimantan Selatan (30,8\%), KalimantanTimur (29,6\%), Jawa Barat (29,4\%), dan Gorontalo $(29,4 \%)$ (KemenkesRI, 2014).

Hipertensi merupakan suatu gangguan pada pembuluh darah yang mengakibatkan suplai oksigen dan nutrisi yang dibawa oleh darah terhambat sampai jaringan yang membutuhkannya. Batas tekanan darah seseorang dikatakan hipertensi apabila tekanan sistolik lebih dari140 $\mathrm{mmHg}$ dan tekanan diastolic $90 \mathrm{mmHg}$ pada orang yang tidak menderita diabetes melitus, sedangkan pada penderita diabetes mellitus dan jantung tekanan darahp enderita hipertensii bawah 130/90 mmHg (Ignatavicius \& Workman, 2018).

Insidensi hipertensi dihampir semua negara menunjuk kanangka yang cukup tinggi. Tahun 2015 terdapat 285 juta penderita hipertensi, Pada tahun 2000 kejadian hipertensi mencapai 639 juta dantahun2025 diperkirakan 1,15 milyar kasus (Armilawaty, Amalia \& Amirudin, 2007). Di Indonesia menurut hasil survey kesehatan rumah tangga tahun 2004 menunjukkan prevalensi hipertensi di Indonesia cukup tinggi, yaitu 83 per 1000 anggota rumah tangga. Sedangkan menurut TheI nternational Clinical Epidemiology Network (INCLN) prevalensi hipertensi di Indonesia mencapai 23\% (Sharma, etal., 2018).

Pada saat ini masih banyak masyarakat yang belum mengetahui cara mengontrol hipertensi dengan benar. Hipertensi dapatd ikontrol dengan 2 cara yaitu farmakologi dan non farmakologi. Tingkat aktivitas merupakan salah satu cara mengontrol hipertensi non farmakologi jika dilakukan secara rutin dan teratur, apalagi jaman sekarang tekhnologi semakin canggih yang membuat orang semakin malas untuk beraktifitas, ini merupkan resiko utama peningkatan tekanan darah (A.j. Ramadhan, 2018).

Brisk walking exercise merupakan salah satu bentuk latihan aerobik merupakan bentuk pada pasien hipertensi dengan menggunakan tehnik jalan cepat selama 20-30 menit dengan rata-rata kecepatan 4-6 $\mathrm{km} / \mathrm{jam}$. Kelebihan latihan ini adalah latihan ini cukup efektif untuk meningkatkan kapasitas maksimal denyut jantung, merangsang kontraksi otot, pemecah anglikogen dan peningkatan oksigen jaringan. Latihan ini juga dapat mengurangi pembentukan plak melalui peningkatan penggunaan lemak dan peningkatan penggunaan glukosa (Kowalski, 2015).

Brisk walking exercise juga berdampak pada penurunan risiko mortalitas dan morbiditas pasien hipertensi yang melalui mekanisme pembakaran kalori, mempertahankan berat badan, membantu tubuh rileks dan peningkatan senyawa betaendorphin yang dapat menurunkan stress serta tingkat keamanan penerapan brisk walking exercise pada semua tingkat umur penderita hipertensi (Kowalski, 2015).

Sukarmin (2013), menjelaskan bahwa Brisk walking exercise sebagai salah satu bentuk latihan aerobik merupakan bentuk latihan aktivitas sedang pada pasien hipertensi dengan menggunakan tehnik jalan cepat selama 20-30 menit dengan rerata kecepatan 4-6 km/jam. Kelebihannya adalah latihan ini cukup efektif untuk meningkatkan kapasitas maksimal denyut jantung, merangsang kontraksi otot, pemecahan glikogen dan peningkatan oksigen jaringan. Latihan ini juga dapat mengurangi pembentukanp lak melalui peningkatan penggunaan lemak dan peningkatan penggunaan glukosa. Brisk walking exercise berdampak pada penurunan risiko mortalitas dan morbiditas pasien hipertensi melalui mekanisme pembakaran kalori, mempertahankan 
berat badan, membantu tubuh rileks dan peningkatan senyawa betaendhorphin yang dapat menurunkan stres serta tingkat keamanan penerapan brisk walking exercise pada semua tingkat umur penderita hipertensi.

Nuryanto (2016), menjelaskan bahwa Brisk walking exercise merupakan salah satu aktivitas fisik yaitu berjalan cepat dari pada kecepatan anda berjalan normal dengan waktu yang ditentukan serta dalam jarak tertentu. Brisk walking adalah olahraga terbaik dan dianjurkan untuk umur 40 tahun atau lebih, karena Brisk walking (Jalan Cepat) tidak berat dilakukan untuk usia tersebut. Brisk walking exercise berdampak pada penurunan risiko mortalitas dan morbiditas pasien hipertensi melalui mekanisme pembakaran kalori, mempertahankan berat badan, membantu tubuh rileks dan peningkatan senyawa beta endorphin yang dapat menurunkan stres serta tingkat keamanan penerapan brisk walking exercise pada semua tingkat umur penderita hipertensi (Kowalski, 2015).

Target penurunan tekanan darahyang belum optimaldan belum adanya penerapan brisk walking exercise pada penatalaksanaan pasien hipertensi di UPT Pelayanan Sosial Lanjut Usia Kisaran Rantau Prapat, mendorong penelitian ini. Tujuan penelitian ini adalah mengidentifikasi pengaruh brisk walking exercise terhadap tekanan darah pasien hiper- tensi

Berdasarkan survey awal yang dilakukan di UPT Pelayanan Sosial Lanjut Usia Kisaran Rantau Prapat pada tanggl 23 November 2019 dengan mewawancari 10 lansia, 8 lansia terkenan hipertensi dengan derajat hipertensi derajat 3 dan tidak pernah melakukan olah raga, 2 lansia terkenan hipertensi pernah melakukan Brisk walking exercise tapi tidak teratur.

Berdasarkan latar belakang yang telah dikemukakan diatas maka penulis tertarik melakukan penelitian mengenai Pengaruh metode "Brisk Walking Exercixe" terhadap penurunan tekanan darah pada pasien hipertensi di UPT Pelayanan Sosial Lanjut Usia Kisaran Rantau Prapat Tahun 2020.

\section{RESEARCH METHOD}

Penelitian ini menggunakan jenis penelitian Pre-eksperimental designOne Group pre-test and posttest design. Populasi dalam penelitian ini adalah seluruh lansia yang mengalami hipertensi di UPT Pelayanan Sosial Lanjut Usia Kisaran Rantau Prapat tahun 2020 yaitu sebanyak 50 lansia penelitian ini mengunakan teknik Teknik Purposive Sampling dimana sampel penilitian berjumlah 40, analisis statistik data yang digunakan pada penelitian ini berupa univariant dan bivarian yaitu mengunakan Uji Wilcoxon.

\section{RESULTS AND ANALYSIS}

\subsection{Hasil}

\section{Analisa Univariat}

\section{Karakteristik Responden}

Karakteristik responden pada penelitian ini dikelompokkan berdasarkan umur, jenis kelamin, dan lama menderita hipertensi. Karakteristik resonden diuraikan dalam tabel 1 sebagai berikut:

Tabel 1. Karakteristik Responden di UPT Pelayanan Sosial Lanjut Usia Kisaran Rantau Prapat Tahun 2020

\begin{tabular}{clcc}
\hline No & Data Demografi & Frekuensi & Persentase (\%) \\
\hline $\mathbf{1}$ & Umur & & \\
& $45-60$ tahun & 35 & 87,5 \\
& $>60$ tahun & 5 & 12,5 \\
\hline \multirow{2}{*}{ Jumlah } & Jenis Kelamin & 40 & 100 \\
& Laki-laki & 27 & 67,5 \\
& Perempuan & 13 & 32,5 \\
\hline & Jumlah & 40 & 100 \\
\hline $\mathbf{3}$ & Lama Menderita Hipertensi & & \\
& 1-5 tahun & 28 & 70,0 \\
& 6-10 tahun & 10 & 25,0 \\
& $>10$ tahun & 2 & 5,0 \\
\hline & Jumlah & 40 & 100
\end{tabular}

Berdasarkan tabel 1 sebagian besar responden yang berkunjung ke UPT Pelayanan Sosial Lanjut Usia Kisaran Rantau Prapat Tahun 2020 mayoritas berusia antara 45 -60 tahun yaitu 35 responden $(87,5 \%)$ dan sebagian besar responden berjenis kelamin laki-laki yaitu 27 responden $(67,5 \%)$ dengan keadaan pasien sudah lama menderita hipertensi sudah mencapai 1-5 tahun yaitu sebanyak 28 responden (70,0\%). 


\section{Tekanan Darah Pada Pasien Hipertensi Sesudah Dilakukannya Metode "Brisk Walking Exercixe" Pasien Hipertensi}

Data tekanan darah pada pasien hipertensisesudah dilakukannya metode "Brisk Walking Exercixe" pasien hipertensi di UPT Pelayanan Sosial Lanjut Usia Kisaran Rantau Prapat Tahun 2020 dapat dilihat pada tabel 2 berikut:

Tabel 2.Tekanan Darah Pada Pasien Hipertensisesudah Dilakukannya Metode "Brisk Walking Exercixe” Pasien Hipertensi Di Upt Pelayanan Sosial Lanjut Usia Kisaran Rantau Prapat Tahun 2020

\begin{tabular}{lcc}
\hline $\begin{array}{l}\text { Tekanan Darah Pada Pasien Hipertensi Sesudah } \\
\text { Dilakukan Metode "Brisk Walking Exercixe" }\end{array}$ & Frekuensi & \% \\
\hline Pre hipertensi & 36 & 90,0 \\
\hline Hipertensi tahap 1 & 4 & 10,0 \\
\hline Hipertensi tahap 2 & 0 & 0,0 \\
\hline Jumlah & $\mathbf{4 0}$ & $\mathbf{1 0 0}$ \\
\hline
\end{tabular}

Berdasarkan tabel 2 di atas menunjukkan bahwa tekanan darah pasien sesudah dilakukan brisk walking exersice sebagian besar mengalami pre hipertensi (120-139 $\mathrm{mmHg}$ ) sebanyak 36 responden $(25,0 \%)$, sedangkan sebagian kecil responden mengalami hipertensi tahap 1 (140-159 mmHg) sebanyak 4 responden $(10,0 \%)$.

\section{Penurunan Tekanan Darah Pada Pasien Hipertensi Sebelum Dan Sesudah Dilakukannya Metode} “Brisk Walking Exercixe” Pasien Hipertensi

Data penurunan tekanan darah pada pasien hipertensisebelum dan sesudah dilakukannya metode "Brisk Walking Exercixe" pasien hipertensi di UPT Pelayanan Sosial Lanjut Usia Kisaran Rantau Prapat Tahun 2020 dapat dilihat pada tabel 3 berikut :

Tabel 3. Penurunan Tekanan Darah Pada Pasien Hipertensisebelum Dan Sesudah Dilakukannya Metode “Brisk Walking Exercixe” Pasien Hipertensi Di Upt Pelayanan Sosial Lanjut Usia Kisaran Rantau Prapat Tahun 2020

\begin{tabular}{lcc}
\hline $\begin{array}{l}\text { Penurunan Tekanan Darah Pada Pasien Hipertensi Sebelum } \\
\text { dan Sesudah dilakukan metode "Brisk Walking Exercixe” }\end{array}$ & Frekuensi & \% \\
\hline Menurun & 37 & 92,5 \\
\hline Tetap & 3 & 7,5 \\
\hline Meningkat & 0 & 0,0 \\
\hline Jumlah & $\mathbf{4 0}$ & $\mathbf{1 0 0}$ \\
\hline
\end{tabular}

Berdasarkan tabel 3 di atas menunjukkan bahwa tekanan darah pasien sebelum dan sesudah dilakukan brisk walking exersice sebagian besar mengalami penurunan hipertensi sebanyak 37 responden $(92,5 \%)$, sedangkan tekanan darah yang tetap sebanyak 3 responden $(7,5 \%)$.

\section{Pengaruh metode "Brisk Walking Exercixe" terhadap penurunan tekanan darah pada pasien} hipertensi

Hasil uji statistik pengaruh metode "Brisk Walking Exercixe" terhadap penurunan tekanan darah pada pasien hipertensi di UPT Pelayanan Sosial Lanjut Usia Kisaran Rantau Prapat Tahun 2020 terdapat pada tabel 4 sebagai berikut:

Tabel 4. Pengaruh metode "Brisk Walking Exercixe" Terhadap Penurunan Tekanan Darah Pada Pasien Hipertensi Di Upt Pelayanan Sosial Lanjut Usia Kisaran Rantau Prapat Tahun 2020

\begin{tabular}{|c|c|c|c|c|c|}
\hline \multirow{3}{*}{$\begin{array}{l}\text { Tekanan Darah Pada } \\
\text { Pasien Hipertensi }\end{array}$} & \multicolumn{2}{|c|}{ Perlakuan } & \multirow{2}{*}{\multicolumn{2}{|c|}{ Perubahan Ranking }} & \multirow{2}{*}{ p value } \\
\hline & Sebelum & Sesudah & & & \\
\hline & $\mathbf{f}$ & $\mathbf{f}$ & & $\mathbf{F}$ & \\
\hline - Pre hipertensi & 10 & 36 & Rangking Positif & 0 & \\
\hline - Hipertensi tahap 1 & 30 & 4 & Rangking Negatif & 26 & $0,000^{*}$ \\
\hline - Hipertensi tahap 2 & 0 & 0 & Ties & 14 & \\
\hline
\end{tabular}

Keterangan : a) Uji Wilcoxon

Perubahan Penurunan tekanan darah :

a. Ranking Negatif adalah perubahan penurunan tekanan darah sebelum dan sesudah dari kategori 'pre hipertensi' menjadi kategori ' hipertensi tahap $1^{\text {' }}$

b. Ranking Positif adalah perubahan sebelum dan sesudah dari kategori 'hipertensi tahap 1' menjadi 'pre hipertensi' 
c. Ties artinya tidak terjadi perubahan sebelum dan sesudah

Berdasarkan tabel 4 di atas menunjukan tekanan darah sistol dan diastole sebelum dan sesudah dilakukannya brisk walking exersice mengalami perubahan. Tekanan darah sistol sebelum dilakukan brisk walking exersice sebanyak 30 responden masuk dalam kategori hipertensi tahap 1 (140-159 mmHg) berkurang menjadi 4 responden sesudah dilakukan brisk walking exersice. Sedangkan tekanan darah diastole sebelum dilakukan brisk walking exersice sebanyak 10 responden masuk dalam kategori pre hipertensi (120$139 \mathrm{mmHg}$ ) setelah dilakukan brisk walking exersice sebagian besar bertambah menjadi 36 responden.

Berdasarkan Hasil uji statistic dengan menggunakan Uji Wilcoxon menggunakan bantuan SPSS 20.0 diketahui bahwa nilai $\mathrm{p}(0,000)<\alpha(0,05)$ artinya Ho ditolak, jadi terdapat pengaruh yang signifikan metode "Brisk Walking Exercixe" terhadap penurunan tekanan darah pada pasien hipertensi di UPT Pelayanan Sosial Lanjut Usia Kisaran Rantau Prapat Tahun 2020.

\subsection{Pembahasan}

\section{Karakteristik Responden Dengan Kejadian Hipertensi Pada Pasien Di UPT Pelayanan Sosial Lanjut} Usia Kisaran Rantau Prapat Tahun 2020

Berdasarkan data demografi sebagian besar responden yang berkunjung ke UPT Pelayanan Sosial Lanjut Usia Kisaran Rantau Prapat Tahun 2020 mayoritas berusia antara 45 -60 tahun yaitu 35 responden $(87,5 \%)$ dan sebagian besar responden berjenis kelamin laki-laki yaitu 27 responden $(67,5 \%)$ dengan keadaan pasien sudah lama menderita hipertensi sudah mencapai 1-5 tahun yaitu sebanyak 28 responden (70,0\%).

Berdasarkan data demografi bahwa banyaknya lansia yang mengalami hipertensi diusia 45-60 tahun hal ini sesuai dengan, Undang-Undang Nomor 13 Tahun 1998 dalam Azizah (2011) tentang kesejahteraan lanjut usia pada bab I pasal 1ayat 2, yang dimaksud lanjut usia adalah seseorang yang mencapai usia 60 tahun keatas. Lansia merupakan proses alami yang dialami oleh semua orang, dimasa ini seseorang akan mengalami kemunduran fisik, mental dan sosial secara bertahap. Kemunduran fungsi organ juga terjadi pada lansia yang menyebabkan kelompok ini rawa nterhadap penyakit-penyakit kronis seperti Diabetes Melitus, stroke, gagal ginjal dan hipertensi. Salah satu masalah kesehatan yang sering terjadi pada masa usia lanjut adalah hipertensi atau tekanan darah tinggi (Kemenkes RI, 2013).

Hasil penelelitian sesuai dengan UUD bahwa lansia banyak menderita hipertensi karena adalah laki-laki dikarena laki- laki memiliki pola hidup yang tidak sehat dan kurangnya dalam berolah raga dan rata - rata penderita hipertensi 1-5 tahun dimulai mereka pada saat sudah memasuki usia lansia.

Salah satu masalah kesehatan yang sering terjadi pada masa usia lanjut adalah hipertensi atau tekanan darah tinggi. Hipertensi merupakan terjadiny apeningkatan secara abnormal dan terus menerus tekanan darah yang disebabkan satu atau beberapa faktor yang tidak berjalan sebagaimana mestinya dalam mempertahankan tekanan darah secara normal (Levine \& Fodor, 2013). Hipertensi pada usia lanjut sebagian besar merupakan hipertensi sistolik terisolasi (HST) (Kuswardhani, 2016). Hipertensi sistolik terisolasi adalah hipertensi yang terjadi ketika tekanan sistolik lebih dari $140 \mathrm{mmHg}$ namun tekanan diastolic dalam batas normal (Wahid, 2017).

Sekitar 60\% lansia akan mengalami hipertensi setelah berusia 75tahun. Hal ini merupakan pengaruh degenerasi yang terjadi pada orang yang bertambah usianya. Data dari The National Health and Nutrition Examination Survey (NHANES) menunjukkan bahwa dari tahun 2000-2015, insiden hipertensi pada orang dewasa adalah sekitar 29-31\%, yang berarti terdapat 58-65 juta penderita hipertensi di Amerika (Yogiantoro, 2016). Berdasarkan data Depkes (2015), prevalensi hipertensi di Indonesia sebesar 31.7\%. Cakupan diagnosis hipertensi oleh tenaga kesehatan hanya mencapai $24.0 \%$, atau dengan kata lain sebanyak $76.0 \%$ kejadian hipertensi dalam masyarakat belum terdiagnosis. Dari hasil studi tentang kondisi sosial ekonomi dan kesehatan lanjut usia yang dilaksanakan Komnas Lansia di 10propinsi tahun 2012, diketahui bahwa hipertensi menduduki peringkat kedua penyakit terbanyak yang diderita lansia setelah penyakit sendi (Depkes, 2016).

Asumsi peneliti mengatakan bahwa umur, jenis kelamin dan lamanya mnederita hipetensi mempengaruh peningkatan terjadinya hipetensi pada lansia, sehingga di perlukanaya "Brisk Walking Exercix" untuk mengurahi terjadnya hipetensi dan komplikasi yang akan terjadi apabila tidak ditanganinya tekanan darah padalansia tersebut.

\footnotetext{
Tekanan Darah Pada Pasien Hipertensi Sebelum Dilakukannya Metode “Brisk Walking Exercix" Pasien Hipertensi Di UPT Pelayanan Sosial Lanjut Usia Kisaran Rantau Prapat Tahun 2020

Berdasarkan hasil penelitian didapatkan bahwa tekanan darah pasien sebelum dilakukan brisk walking exersice sebagian besar mengalami hipertensi tahap 1 (140-159 mmHg) sebanyak 30 responden $(25,0 \%)$, sedangkan sebagian kecil responden mengalami pre hipertensi (120-139 mmHg) sebanyak 10 responden $(25,0 \%)$.
} 
Tekanan darah adalah kekuatan, tegangan atau tekanan yang digunakan oleh darah yang bersirkulasi pada dinding-dinding dari pembuluh-pembuluh darah, dan merupakan satu dari tanda-tanda vital yang utama dari kehidupan, yang juga termasuk detak jantung, kecepatan pernapasan, dan temperature. (Muhammadun AS, 2015)

Dilihat dari faktor-faktor preventif meliputi jenis kelamin, usia, kelebihan berat badan, kebiasaan merokok dan kebiasaan mengkonsumsi garam. Faktor pertama yang mempengaruhi yaitu jenis kelamin. Dari data tabel 4.1 didapatkan bahwa sebagian besar atau hampir keseluruhan responden berjenis kelamin laki-laki sebanyak 27 responden. Tekanan darah pada pria lebih tinggi dibandingkan dengan tekanan darah pada wanita karena pria mempunyai hormon testosteron yang menyebabkan pembuluh darah tidak seelastis pembuluh darah pada wanita dan memiliki Total Peripheral Resistance yang tinggi. Jenis kelamin adalah merupakan faktor penyebab hipertensi yang tidak dapat di kendalikan kaena sudah menjadi hal yang mutlak sejak lahir, untuk itu penelti menyimpulkan tekanan daah tinggi lebih banyak di temukan pada perempuan dibandingkan laki laki karena faktor faktor seperti obesitas dan kuangnya aktivitas. (Widiarto, 2018).

Faktor yang kedua yaitu usia semakin tua usia seseorang semakin beresiko mengalami penigkatan tekanan darah. Berdasarkan tabel 1 menunjukkan bahwa sebagian besar responden berusia 45-60 tahun sebanyak 35 responden (87,5\%). Menurut penelitian Purnamasari (2018) bahwa selain faktor usia, faktor obesitas, dan merokok juga merupakan factor pemicu penyakit hipertensi. Seluruh responden laki-laki merokok, merokok dapat memicu hipertensi karena rokok mengadung ribuan zat yang berbahaya pada tubuh, seperti tar, nikotin dan gas karbon monoksida. Faktor selanjutnya yaitu konsumsi garam yang sebagian besar responden mengkonsumsi makanan tinggi garam.

Tekanan darah responden pada penelitian ini menunjukkan bahwa sebelum dilakukan Brisk Walking Exersice sebanyak 30 responden (75\%) mengalami hipertensi kategori hipertensi tahap 1. Hal ini karena perubahan pada salah satu fungsi sistemorga tubuh yaitu sistem kardiovaskuler dan adanya penurunan fungsi ginjal yang berperan penting dalam pengendalian tekanan darah yang dialami oleh lansia, melalui sistem reninangiotensin, ginjal mempengaruhi resistensi perifer dan homeostasis natrium, menyebabkan peningkatan volume intra vaskuler.

Dari factor prepitasi yang meliputi jenis kelamin, usia, obesitas, kebiasaan merokok dan konsumsi garam, factor tersebut dapat mendukung terjadinya peningkatan tekanan darah. Untuk itu perlu dilakukan pencegahan dengan cara berperilaku hidup sehat dengan cara menjaga pola makan, olahraga secara teratur dan menghindari rokok. Hal tersebut dilakukan untuk mengontrol tekanan darah dan mengurangi resiko terjadinya hipertensi serta komplikasi hipertensi lebih lanjut.

Peningkatan tekanan darah pada responden dipengaruhi oleh kurangnya olahraga. Menurut Sukarmin (2018) Brisk Walking Exercise dapat menurunkan tekanan darah dengan adanya dilatasi pembuluh darah oleh karena terjadi penurunan resistensi perifer yang menyebabkan otot berkontraksi yang dapat meningkatkan aktivitas fisik dengan begitu aliran darah zkan meningkat 30 kali lipat jika dilakukan secara ritmik.

Asumsi penelitian menyatakan bahwa faktor yang kedua yaitu usia semakin tua usia seseorang semakin beresiko mengalami penigkatan tekanan darah bahwa tekanan darah pasien sebelum dilakukan brisk walking exersice sebagian besar mengalami hipertensi tahap 1 Untuk itu perlu dilakukan pencegahan dengan cara berperilaku hidup sehat dengan cara menjaga pola makan, olahraga secara teratur dan menghindari rokok.

Penurunan Tekanan Darah Pada Pasien Hipertensi Sesudah Dilakukannya Metode "Brisk Walking Exercixe” Pasien Hipertensi Di UPT Pelayanan Sosial Lanjut Usia Kisaran Rantau Prapat Tahun 2020

Berdasarkan hasil penelitian menunjukkan bahwa tekanan darah pasien sesudah dilakukan brisk walking exersixe sebagian besar mengalami pre hipertensi (120-139 mmHg) sebanyak 36 responden $(25,0 \%)$, sedangkan sebagian kecil responden mengalami hipertensi tahap 1 (140-159 $\mathrm{mmHg}$ ) sebanyak 4 responden $(10,0 \%)$

Berdasarkan teori yang ada terdapat berbagai faktor yang mempengaruhi tekanan darah yaitu jenis kelamin, usia, berat badan, kebiasaan merokok dan konsumsi garam yang berlebih, dari beberapa factor tersebut tindakan yang dapat dilakukan yaitu dengan pengobatan secara farmakologi dan non farmakologi. Salah satu tindakan pengobatan secara non farmakalogi yaitu dengan Brisk Walking Exersice yang bermanfaat untuk mengurangi kolesterol jahat di dalam tubuh dan melindungi jantung dari penyakit. Membantu dalam meningkatkan kesehatan kardiovaskular dengan memperkuat paru-paru, otot dan jantung.

Berjalan cepat juga meningkatkan kesehatan jantung dan memompa aliran darah ke seluruh system tubuh. Brisk Walking Exercixe ini tidak memerlukan biaya yang terlalu mahal dan tidak memiliki efek samping yang berbahaya (dalam Nuryanto,dkk, 2016). Apabila tekanan darah tidak mengalami perubahan setelah dilakukan Brisk Walking Exersice itu disebabkan karena dipegaruhi oleh beberapa factor yaitu usia, kebiasaan meroko, obesitas, dan konsumsi garam berlebih. Dan apabila tekanan darah mengalami perubahan 
setelah melakukan Brisk Walking Exersice jika dilakukan dengan tepat, sesuai prosedur dan dilakukan denga rutin dan teratur setiap responden akan memiliki daya tahan tubuh yang prima sehingga dapat berpengaruh terhadap perubahan tekanan darah. Bukan hanya rutin dan teratur saja untuk melakukan Brisk Walking Exersice namun perlu juga untuk memperbaiki pola hidup yang sehat agar tetap bisa mengontrol tekanan darah, dari sinilah tekanan darah akan dapat terkontrol dengan maksimal.

Asumsi Penelitian penurunan tekanan darah yang dialami oleh responden sudah sesuai dengan teori di atas bahwa dalam penatalaksanaan hipertensi tidak untuk menormalkan tekanan darah, akan tetapi menurunkan tekanan sistolik setidaknya $20 \mathrm{mmHg}$ dari tekanan darah awal, hal inilah yang menyebabkan sejumlah responden tidak mengalami perubahan derajat hipertensi, karena penurunan darah yang diakibatkan karena melakukan brisk walking exercise tidak secara drastis namun perlahan-lahan, untuk membiasakan mengurangi beban jantung dalam memompa darah sedikit demi sedikit. Meningkatnya jumlah responden yang tekanan darahnya di bawah ratarata berarti bahwa setelah melakukan brisk walking exercise terjadi penurunan tekanan darah dari sebelumnya.

\section{Pengaruh Metode "Brisk Walking Exercixe" Terhadap Penurunan Tekanan Darah Pada Pasien Hipertensi Di UPT Pelayanan Sosial Lanjut Usia Kisaran Rantau Prapat Tahun 2020}

Berdasarkan hasil penelitian menunjukan tekanan darah sistol dan diastole sebelum dan sesudah dilakukannya brisk walking exersice mengalami perubahan. Tekanan darah sistol sebelum dilakukan brisk walking exersice sebanyak 30 responden masuk dalam kategori hipertensi tahap $1(140-159 \mathrm{mmHg})$ berkurang menjadi 4 responden sesudah dilakukan brisk walking exersice. Sedangkan tekanan darah diastole sebelum dilakukan brisk walking exersice sebanyak 10 responden masuk dalam kategori pre hipertensi (120$139 \mathrm{mmHg}$ ) setelah dilakukan brisk walking exersice sebagian besar bertambah menjadi 36 responden.

Berdasarkan Hasil uji statistic dengan menggunakan uji wilcoxon menggunakan bantuan SPSS 20.0 diketahui bahwa nilai $\mathrm{p}(0,000)<\alpha(0,05)$ artinya Ho ditolak, artinya terdapat pengaruh atau perbedaan yang signifikan antara tekanan darah sebelum dan sesudah dilakukannya Brisk Walking Exersice. Jadi dapat disimpulkan bahwa ada pengaruh Brisk Walking Exersice terhadap penurunan tekanan darah pada pasien hipertensi di UPT Pelayanan Sosial Lanjut Usia Kisaran Rantau Prapat Tahun 2020.

Perubahan tekanan darah sebelum dan sesudah dilakukan Brisk Walking Exersice cenderung mengalami penurunan tersebut dari perubahan tekanan darah sebelum dan sesudah Brisk Walking Exersice didapatkan 37 responden mengalami penurunan tekanan darah sedangkan 3 responden dalam kategori tetap.

Latihan olahraga untuk lansia bertujuan untuk meningkatkan kesehatan jasmani dan kebugaran. Kebugaran jasmani pada lansia adalah kebugaran yang berhubungan dengan kesehatan, yaitu kebugaran jantung, paru-paru peredaran darah, kekuatan otot dan kelenturan sendi. Untuk memperoleh kesegaran jasmani yang baik harus, melatih semua komponen dasar kesegaran jasmani yang terdiri atas ketahan jantung, peredaran darah dan pernafasan, ketahanan otot, kekakuan otot serta kelenturan tubuh (Said Junaidi, 2011).

Brisk walking exercixe sebagai salah satu bentuk latihan aerobic (olahraga) merupakan bentuk latihan aktivitas sedang pada pasien hipertensi dengan menggunakan tehnik jalan cepat selama 20-30 menit dengan rerata kecepatan 4-6 km/jam. Kelebihannya adalah latihan ini cukup efektif untuk meningkatkan kapasitas maksimal denyut jantung, merangsang kontraksi otot, pemecahan glikogen dan peningkatan oksigen jaringan. Latihan ini juga dapat mengurangi pembentukan plak melalui peningkatan penggunaan lemak dan peningkatan penggunaan glukosa (Kowalski, 2010).

Brisk walking exercixe berdampak pada penurunan risiko mortalitas dan morbiditas pasien hipertensi melalui mekanisme pembakaran kalori, mempertahankan berat badan, membantu tubuh rileks dan peningkatan senyawa beta endorphin yang dapat menurunkan stres serta tingkat keamanan penerapan brisk walking exercise pada semua tingkat umur penderita hipertensi (Kowalski, 2015).

Telah banyak penelitian sebelumnya yang mendukung pernyataan bahwa aktivitas fisik berpengaruh terhadap tekanan darah pada hipertensi seperti penelitian yang dilakukan oleh Sukarmi dkk. (2013). Dari hasil penelitian tersebut, diketahui bahwa pada pasien hipertensi apabila melakukan Brisk Walking Exersice secara teratur selama seminggu dengan frekwensi 3-5 kali dalam waktu 30 menit setiap latihan akan menurunkan tekanan darah yang signifikan.

Asumsi penelitian pengaruh brisk walking terhadap tekanan darah menunjukkan adanya penurunan tekanan darah setelah brisk walking exercise secara signifikan. Penurunan tekanan darah pada kelompok intervensi mungkin tidak hanya disebabkan oleh pengaruh brisk walking saja akan tetapi diet rendah garam yang diberikan pada pasien hipertensi dan obat-obat anti hipertensi juga turut berperan serta dalam menurunkan tekanan darah. Diet rendah garam yang diberikan pada pasien hipertensi pada kelompok kontrol mungkin bersinergi dengan peningkatan pengeluaran ion natrium melalui keringat pada saat brisk walking (Sukarmin, 2013). 


\section{CONCLUSION}

Berdasarkan uraian dari hasil penelitian, maka dapat disimpulkan sebagai berikut:

1. Tekanan darah pasien hipertensi sebelum dilakukan brisk walking exersice sebagian besar mengalami hipertensi tahap 1 (140-159mmHg)

2. Tekanan darah pasien sesudah dilakukan brisk walking exersice sebagian besar mengalami pre hipertensi $(120-139 \mathrm{mmHg})$

3. Ada pengaruh atau perbedaan yang signifikan antara tekanan darah sebelum dan sesudah dilakukannya Brisk Walking Exersice, dengan nilai p $(0,000)<\alpha(0,05)$. Perubahan tekanan darah sebelum dan sesudah dilakukan Brisk Walking Exersice cenderung mengalami penurunan terbuti dari perubahan tekanan darah sebelum dan sesudah Brisk Walking Exersice didapatkan 37 responden mengalami penurunan tekanan darah sedangkan 3 responden dalam kategori tetap. Jadi dapat disimpulkan bahwa ada pengaruh yang signifikan Brisk Walking Exersice terhadap penurunan tekanan darah pada pasien hipertensi di UPT Pelayanan Sosial Lanjut Usia Kisaran Rantau Prapat Tahun 2020.

\section{REFERENCES}

Ali, Z. (2015). Pengantar Keperawatan Keluarga. Jakarta: EGC.

Anggarini, F.(2011). Hubungan antara tingkat perawatan diri ansia dengan perubahan konsep diri lansia di UPT Pelayanan Sosial Lanjut Usia dan Anak Balita wilayah Binjai dan Medan. Diakses pada tanggal 4 Oktober, 2018, dariwww.repository.usu.ac.id.

BPS Kota Medan .(2012). Kecamatan Medan Johor dalam Angka. Medan: BPS dan Badan Perencanaan Pembangunan Daerah Kota Medan.

BPS Kota Medan. (2017). Kecamatan Medan Johord alam Angka. Medan: BPS dan Badan Perencanaan Pembangunan Daerah Kota Medan.

Bratanegara, A. S., Manat,L., Nur, O. H. (2012). Gambaran dukungan keluarga terhadap pemanfaatan posbindu lansia di Kelurahan Karasak Kota Bandung. Diakses pada tanggal 25 September, 2018, dari http://download.portalgaruda.org/article.php?article=103955\&val=1378.

BKKBN. (2012). Lansia. Diakses pada tanggal 30 September, 2018, dari http://www.bkkbn.go.id.

Dalami, E., Suliswati, Pipin, F., Rochimah, Endang, B. (2016). Asuhan keperawatan jiwa dengan masalah psikososial. Jakarta: Trans Info Media.

Depkes. (2015). Jumlah Penduduk Lanjut Usia Meningkat. Dibuka 12 September 2018 dari http://www.depkes.go.id

Depkes. (2016). Jumlah Penduduk Lanjut Usia Meningkat. Dibuka 12 September 2018 dari http://www.depkes.go.id

Friedman, M. M. (2013). Family nursing: Reasearch, theory \& practice fourt edition. Appleton \& Lange, Stamford CT: Prentice Hall.

Kresnawati, I. \& Kartinah. (2011). Hubungan dukungan keluarga dengan keaktifan lansia dalam mengikuti kegiatan di posyandu lansia Desa Gonilan KecamatanKartasura. Diakses tanggal 8 Desember, 2018, dari http://publikasiilmiah.ums.ac.id.

Notoatmodjo, S. (2010). Metodologi penelitian kesehatan. Jakarta: Rineka Cipta.

Notoatmodjo, S. (2013). Promosi Kesehatan dan Ilmu Perilaku. Jakarta: Rineka Cipta.

Nugroho, W. (2015). Keperawatan gerontik edisi 3. Jakarta: EGC.

Romadlani, R., Tri, N., Agustin, S. (2013). Hubungan dukungan keluarga dan kemandirian lansia dengan konsep diri lansia di Kelurahan Bambankerep Kecamatan Ngaliyan Kota Semarang. Jurnal Keperawatan Komunitas,1(1), 18-23. Diakses pada tanggal 16 September, 2018, dari http://jurnal.unimus.ac.id/index.php/JKK/article/view/921/973.

Rosmaini, Hasibuan,. 2018. Penurunan tekanan darah pada pasien hipertensi melalui brisk walking excercise, Jurnal Keperawatan Indonesia volume 16 no, Maret 2013, hal 33-39

Setiadi. (2014). Konsep dan penulisan riset keperawatan. Yogyakarta: Graha Ilmu.

Setiadi. (2015). Konsep dan proses keperawatan keluarga. Yogyakarta: Graha Ilmu.

Kristyaningsih, D. (2016). Hubungan antara dukungan keluarga dengan tingkat depresi pada lansia. Jurnal Keperawatan, 1 (1). Diakses pada tanggal 25 September, 2018, dari www.dianhusada.ac.id/jurnalimg/jurper1-10-dew.pdf.

Tamher, S. \& Noorkasiani. (2015). Kesehatan usia lanjut dengan pendekatan asuhan keperawatan. Jakarta: Salemba Medika.

Wahid, Ibnu Dian. (2017). Hipertensi pada Lansia. Dibuka 10 September2 018 dari http://diyoyen.blog. friendster.com/2008/09/hipertensi-pada-lansia/

WHO. World $\quad$ health
http://apps.who.int/iris/bitstream/10665/44844/1/9789241564441_eng.pdf. padatanggal 3 Maret 2016.

